\title{
SPRÁVNÍ ČINNOSTI V OBORU STÁTNÍ SLUŽBY
}

\author{
MARTIN KOPECKÝ
}

\begin{abstract}
Performance of Public Administration in Area of Civil Service
The paper analyses specifics of legal status of civil servants responsible for public governance at public authorities according to Civil Service Act nr. 234/2014. Civil servants enter into legal relationships with authorities which decide on behalf of state about appointment of state servant and about changes, termination and performance of service relationship. On the other hand, civil servants perform their work as dependant work and they are subordinated to superior persons (senior civil servants). Deciding about rights and duties of state servants belongs to area of public law, which is different to general regulation of work relationship according to Labour Code, which belongs to area of private law. Authorities executing governance of civil service principally release administrative acts, but also use different instruments as public law contracts or internal (service) regulations. The paper analyses specifics of this instruments in area of civil service.
\end{abstract}

Keywords: civil servant; civil service; civil service relationship

Klíčová slova: státní zaměstnanec; státní služba; služební poměr

DOI: $10.14712 / 23366478.2020 .15$

\section{1. ÚVODEM - DRUHY A CHARAKTER SPRÁVNÍCH ČINNOSTÍ V OBORU STÁTNÍ SLUŽBY}

Problematika právní úpravy státní služby, která ve své civilní složce reálně desítky let u nás neexistovala a začala se uplatňovat až spolu se zákonem č. 234/2014 Sb., o státní službě (ZSS), vyvolává mnoho otázek nejen při jejím praktickém uplatňování, ale i z obecného teoretického pohledu. Bylo sice již vydáno více komentářu k zákonu o státní službě, ${ }^{1}$ vyšlo několik sborníků z konferencí na téma státní služby, ${ }^{2}$ bylo publikováno více časopiseckých článků, sekce pro státní službu ministerstva vnitra vydala více metodických pokynů a stanovisek, objevuje se již i judikatura k výkladu některých institutů této úpravy, obecnější správněprávní zpracování této tematiky však stále schází. Pokusím se tento deficit trochu napravit a ukázat na subjekty právních

1 Např. PICHRT, J. a kol. Zákon o státni službě. Komentář. Praha: Wolters Kluwer 2015; KOTTNAUER, A. - PŘIB, J. - ÚLEHLOVÁ, H. - TOMANDLOVÁ, L. Zákon o státni službě. Ostrava: Sagit 2015; VAVERA, F. - HULÍNSKÝ, P. - MLSNA, P. - MATES, P. - CHRÁSTKOVÁ, K. - DOLEŽÍLEK, J. - ŠKODA, J. Zákon o státni službě s poznámkami. Plzeň: A. Čeněk, 2015.

2 Např. PICHRT, J. - KOPECKÝ, M. - MORÁVEK, J. (eds.). Služebni vztahy a výkon závislé práce. Praha: Wolters Kluwer, 2016; SKULOVÁ, S. - KLIKOVÁ, A. - VALDHANS, J. (eds.). Dny práva 2015 - Days of law 2015, část IX. Veřejná služba ve veřejné správě (a to i jako služba veřejnosti). Brno: Masarykova univerzita, 2016. 
vztahů vznikajících v oblasti státní služby a na specifika správních činností, které jsou při tom činěny.

Základ právní úpravy státní služby, tak jak alespoň vyplývá u nás ze zákona o státní službě, a jak měl i historicky tradici, která se projevila mj. v úpravě služební pragmatiky z r. 1914, ${ }^{3}$ je veřejnoprávní. Výstižnou charakteristiku různého postavení veřejných zaměstnanců ve veřejné správě, a to bud' soukromoprávního, nebo veřejnoprávního, podal v minulosti ve Slovníku veřejného práva československého Vilém Krejčí, když vyložil, že v případě soukromoprávního služebního poměru, založeného podle modifikovaných předpisů obecného občanského zákoníku (1811) o služební smlouvě, měl zaměstnanec omezeny služební povinnosti, ale i práva zpravidla jen na obor služby, zatímco veřejný zaměstnanec, jehož poměr byl založen zejména služební pragmatikou, přijímá svým ustanovením jednostranně určené i služební povinnosti zasahující mimo obor jeho služební činnosti. ${ }^{4}$ Rovněž Jiří Hoetzel v již citovaném Slovníku, a to v hesle Dualismus právní, zdůrazňoval výrazný dopad přeměny původně soukromoprávního poměru státního zaměstnance (úředníka) na vztah veřejnoprávní (publicistický). ${ }^{5} \mathrm{~V}$ jedné ze svých posledních publikovaných prací psala Taisia Čebišová o hybridním řešení služebních vztahů zaměstnanců, kteří vykonávají státní správu, když ZSS konstituuje tyto vztahy jako vztahy sui generis, a to vztahy veřejnoprávní, s tím, že v př́ípadě, kdy se vystačí s obecnou pracovněprávní úpravou, zákon odkazuje na instituty (jednotlivá ustanovení) zákoníku práce (zákon č. 262/2006 Sb. - ZP). ${ }^{6}$

K přijetí do služebního poměru, k zařazení na služební místo, ke změnám služebního poměru, ke změnám obsahu služebního místa či k ukončení služebního poměru dochází správním aktem činěným tím, kdo vykonává státní správu na úseku státní služby, případně jiným úkonem či jinou skutečností, s jejíž existencí spojuje veřejné právo nějaké důsledky. ${ }^{7}$ Státní zaměstnanec je v takovém př́ípadě v postavení odpovídajícím postavení adresáta veřejné správy, ve vztahu k němuž vykonávají orgány vykonávající státní správu na úseku státní služby veřejnou moc. Orgánem rozhodujícím v těchto věcech je služební orgán, ve věcech kárné odpovědnosti státního zaměstnance je to kárná komise prvního stupně. ${ }^{8}$

Práva a povinnosti v rámci služebních vztahů státních zaměstnanců mohou být stanoveny v některých př́ipadech i formou dohody se služebním orgánem, která má dle všeho povahu veřejnoprávní smlouvy.

3 Zákon ze dne 25. 1. 1914, č. 15 ř. z., o služebním poměru státních úředníků a státních zřízenců (služební pragmatika).

4 KREJČÍ, V. Zaměstnanci veřejní. In: Slovník veřejného práva československého (uspořádali HOETZEL, J. - WEYR, F.). Svazek V. Brno: Rovnost, 1948, s. 593. Z tohoto pramene vychází v soudobé literatuře např. KOPECKÝ, M. Správní právo. Obecná část. Praha: C. H. Beck 2019, s. 127.

5 HOETZEL, J. Dualismus právní. In: Slovník veřejného práva československého (uspořádali HÁCHA, E. - HOETZEL, J. - WEYR, F. - LAŠTOVKA, K.). Svazek I. Brno: Polygrafia - Rudolf M. Rohrer, 1929, s. 497.

6 ČEBIŠOVÁ, T. Služební vztahy - hybridní úprava. In: PICHRT - KOPECKÝ - MORÁVEK (eds.), c. d., s. 29.

7 Např. pravomocným odsouzením státního zaměstnance za úmyslný trestný čin končí ze zákona jeho služební poměr [\$ 74 odst. 1 písm. a) ZSS].

8 Srov. $\S 162$ odst. 1 a 2 ZSS a $\S 10$ odst. 2 ZSS. 
Od právních vztahů vznikajících v souvislosti s organizací státní služby, kdy je státní zaměstnanec objektem působení orgánu vykonávajícího veřejnou moc na daném úseku státní správy, je třeba odlišit, že státní zaměstnanec výkonem veřejné služby vykonává druh závislé práce, byt' odlišné od základního pracovněprávního vztahu, který by byl založen pracovním poměrem. Státní zaměstnanec při výkonu státní služby přitom vstupuje do organizačně uspořádaných vztahů, kdy oprávnění ukládat mu př́kazy $\mathrm{k}$ výkonu služby náleží vůči němu představeným - osobám, které jsou vůči němu v hierarchicky nadř́zeném vztahu. Tyto vztahy odpovídají jinak poměrům mezi zaměstnancem a vedoucím zaměstnancem zaměstnavatele ve smyslu zákoníku práce. Ukládání př́kazu k výkonu služby nemá povahu výkonu vrchnostenské veřejné správy vůči adresátovi veřejné správy ve vnějších právních vztazích, ale je interním aktem činěným v rámci zaměstnaneckých vztahů. Na tom nic nemění, že vztah státních zaměstnanců v režimu ZSS není modifikovaným soukromoprávním pracovním poměrem, ale komplexně v jiném zákoně, než je zákoník práce, upraveným specifickým státně zaměstnaneckým poměrem veřejného práva. ${ }^{9}$

Zvláštní postavení $\mathrm{v}$ rámci právních vztahů vůči státním zaměstnancům náleží vládě, která může být z tohoto důvodu nejen vrcholným orgánem moci výkonné (čl. 67 odst. 1 ústavního zákona č. 1/1993 Sb., Ústava České republiky [Úst]), ale v některých prŕpadech i správním orgánem ve smyslu $§ 4$ odst. 1 písm. a) zákona č. 150/2002 Sb., soudní řád správní (SŘS). Vláda je zřejmě správním orgánem,

a) vystupuje-li jako služební orgán, a to vi̊či náměstkovi ministra vnitra pro státní službu (náměstek pro státní službu) podle $§ 10$ odst. 1 písm. a) ZSS (na základě pověření vlády může být ale tímto služebním orgánem ministr vnitra) a vůči vedoucímu služebního úřadu, který je ústředním správním úřadem (na základě pověření vlády může být ale tímto služebním orgánem pověřený člen vlády),

b) rozhoduje-li o odvolání náměstka pro státní službu, státního tajemníka nebo ředitele sekce pro státní službu, pokud vykonává pravomoci náměstka pro státní službu z důvodu, že služební místo náměstka pro státní službu není obsazeno, se ze služebního místa odvolá i v př́padě, pokud zvlášt' závažným způsobem porušil služební kázeň nebo se dopustil zaviněného jednání, jímž narušil důstojnost své funkce nebo ohrozil důvěru v jeho nestranné, odborné a spravedlivé rozhodování, nebo že nevykonává službu po dobu delší než 6 měsíců ( 60 odst. 3 ZSS),

c) schvaluje-li systemizaci služebních míst (systemizace) (§ 17 ZSS),

d) schvaluje-li změnu systemizace (§ $18 \mathrm{ZSS}$ ),

e) rozhoduje-li o organizační struktuře správního úřadu (srov. § 17 odst. 3 a 19 odst. 1 ZSS).

Jak systemizace, tak organizační struktura se vztahují k množině státních zaměstnanců $\mathrm{v}$ každém služebním úřadu, mohou však být úkonem závazným pro následné rozhodnutí (správní akt) služebního orgánu o změně služebního poměru konkrétního státního zaměstnance [srov. § 61 odst. 1 písm. c) a $§ 70$ odst. 3 ZSS], a nejsou tak vyloučeny ze soudního přezkumu jako závazný podklad přezkoumávaného rozhodnutí, který nemohl

9 Srov. např. rozsudek Nejvyššího správního soudu (NSS) ze dne 30. 10. 2003, čj. 6 As 29/2003-97 či rozsudek Nejvyššího soudu (NS) ze dne 9. 1. 2013, sp. zn. 30 Cdo 2470/2012. Byt' se tato rozhodnutí týkala př́slušníka Policie České republiky, lze je vztáhnout i na státního zaměstnance podle ZSS. 
být napaden samostatnou žalobou ve správním soudnictví. ${ }^{10}$ Schvalování systemizace ve smyslu § 17 ZSS je především výsledkem politické činnosti vlády jako vrcholného orgánu moci výkonné a souvisí s její politickou odpovědností za personální zajištění výkonu působnosti v jednotlivých služebních úřadech, nicméně s ohledem na závaznost systemizace pro konkrétní správní postupy směřující k případné změně služebního poměru státního zaměstnance ${ }^{11}$ není vyloučena ani její soudní přezkoumatelnost.

Oproti obecné možnosti schvalovat systemizaci na následující kalendářní rok je přípustnost její změny poté, co nabyla účinnosti, je-li jejím důsledkem změna počtu služebních míst, objemu prostředků na platy státních zaměstnanců nebo změna platové tř́ídy státního zaměstnance o více než jednu třídu dolů nebo o dvě třídy nahoru, př́mo $\mathrm{v} \S 18$ ZSS omezena, jen dojde-li ke změně působnosti správního úřadu ${ }^{12}$ nebo dojde-li k podstatné změně podmínek, za kterých byla systemizace schválena.

Povahu abstraktního aktu jako druhu správní činnosti v oboru státní služby mají služební předpisy. Jsou závazným jednostranným úkonem, vydávaným př́ílušným služebním orgánem, zavazujícím státní zaměstnance, jakož i zaměstnance v pracovním poměru vykonávající činnosti v oboru státní služby a osoby ve služebním poměru podle jiného zákona ${ }^{13}$ zařazené $\mathrm{k}$ výkonu služby ve služebním úřadu. Služební předpis je projevem správní činnosti orgánu plnícího úkoly státní správy na úseku personálního zabezpečení výkonu státní služby. Služební předpisy nemají povahu předpisů právních předpisů vydávaných podle čl. 79 odst. 3 Úst na základě a v mezích zákona za podmínek zákonného zmocnění. Jsou určeny osobám činným v rámci státního organismu, $\mathrm{v}$ rámci něhož se uplatňují vztahy nadřízenosti a podřízenosti. Přitom však závaznost služebních předpisů je založena právně, ${ }^{14}$ není určena pouze státním zaměstnancům (či případným jiným zaměstnancům vykonávajícím činnosti v oboru státní služby) podřízeným tomu, kdo služební předpis vydal. Např. služební předpis vydaný náměstkem pro státní službu je závazný pro všechny státní zaměstnance s výjimkou těch, kteř́ vykonávají službu v některých vyjmenovaných služebních úrúadech (u nichž má být i tímto způsobem zajištěn určitý stupeň nezávislosti na aktuální vládní politice), ${ }^{15}$ př̀ičemž náměstkovi pro státní službu jsou hierarchicky podřízeni jen státní zaměstnanci zařazení v sekci pro státní službu Ministerstva vnitra. Vedoucí služebního úřadu nebo státní tajemník může vydat služební předpis, který je závazný i pro státního zaměstnance (či jiného zaměstnance vykonávající činnosti v oboru státní služby) v podřízeném služebním úřadu, je-li pro podřízené služební úřady nezbytná jednotná úprava organizačních věcí služby; ${ }^{16}$ bez zákonného ustanovení stanovícího možnou závaznost

10 Srov. $\$ 75$ odst. 2 Š̌S; v judikatuře rozsudek NSS ze dne 18. 10. 2019, čj. 5 Ads 269/2018-44 (bod 46 odůvodnění).

11 Viz § 61 odst. 1 písm. c) ZSS - převedení na jiné služební místo a § 62 odst. 1 ZSS - zařazení mimo výkon služby z organizačních důvodů.

12 Podle čl. 79 odst. 1 Úst lze působnost správního úřadu stanovit pouze zákonem.

13 Zákon č. 361/2003 Sb., o služebním poměru př́íslušníků bezpečnostních sborů, zákon č. 221/1999 Sb., o vojácích z povolání.

14 Viz zejm. § 11 odst. 3 ZSS uvádějící, pro koho je služební předpis závazný, § 87 ZSS definující služební kázen̆, zahrnující mj. ráádné plnění povinností státního zaměstnance vyplývající mj. ze služebních předpisů a $§ 77$ odst. 1 písm. f) ZSS o povinnosti státního zaměstnance dodržovat služební kázeň.

$15 \S 11$ odst. 5 ZSS.

16 Viz $§ 11$ odst. 6 ZSS. 
služebního předpisu i pro státní zaměstnance v podřízeném služebním úřadu by je např. nemohl státní tajemník zavazovat svým služebním předpisem, nebot' mu nejsou (s výjimkou vedoucího podř́zeného služebního úřadu jako služebního orgánu) hierarchicky podř́zeni. ${ }^{17}$

Další text je věnován některým druhům správních činností v oboru státní služby podrobněji. Uvádím, že se článek nevěnuje faktickým úkonům a neregulativním úkonům, ač i ty se mohou v oboru státní služby objevovat.

\section{SPRÁVNÍ AKTY VYDÁVANÉ SLUŽEBNÍM ORGÁNEM}

Služební orgán ${ }^{18}$ podle $\S 10$ odst. 2 ZSS ,jedná a rozhoduje ve věcech služebního poměru“. Jedná se o činnost, která směřuje k vydání správního aktu (rozhodnutí) ve věci konkrétního státního zaměstnance. Do této působnosti se řadí rozhodování ve věcech upravených př́mo ZSS (o přijetí do služebního poměru, o jeho změně a skončení, o zařazení na služební místo, o jmenování na služební místo představeného, o odměňování státního zástupce atd.), ale i v dalších věcech týkajících se služebního poměru, u nichž se na základě zákonné delegace užije hmotněprávní úprava jiného zákona (např. věci náhrady škody a nemajetkové újmy v prŕípadě odpovědnosti státního zaměstnance za škodu a odpovědnosti služebního úřadu za škodu a zabezpečení státního zaměstnance při služebním úrazu nebo nemoci z povolání19). Služební orgán nerozhoduje ve věcech kárné odpovědnosti, k tomu je příslušná kárná komise prvního stupně, odvolacím orgánem je pak kárná komise druhého stupně.

V minulosti byla obecná úprava správního řízení pro řízení ve věcech státních zaměstnanců vyloučena. Např. podle $\S 1$ odst. 2 vládního nařízení č. 8/1928 Sb., o řízení ve věcech náležejících do působnosti politických úřadů (správní řízení), ,[n]ařizení se nevztahuje na ř́zení ve věcech služebního poměru státních zaměstnancü. Výluku stanovil i § 2 písm. a) zákona č. 71/1967 Sb., o správním rrízení (správní řád): „Ustanovení tohoto zákona se nevztahuji a) na postup, v němž správni orgány rozhoduji o právních poměrech organizací, pracovníků nebo funkcionářù, jestliže tyto poměry souvisí s jejich podřizeností orgánu, který o věci rozhoduje..."

Zrušený zákon č. 218/2002 Sb., o službě státních zaměstnanců ve správních úřadech a o odměňování těchto zaměstnanců a ostatních zaměstnanců ve správních úřadech (slu-

17 Poradní sbor náměstka ministra vnitra pro státní službu k zákonu o státní službě přijal dne 16. 3. 2018 závěr č. 20, v současnosti již překonaný, že služební předpis vydaný služebním orgánem v nadřizeném služebním úřadu není bez dalšího závazný pro zaměstnance zařazené k výkonu státní služby v podřízených služebních úřadech; služební orgán v nadřízeném služebním úřadu může zavázat služební orgán v podřízeném služebním úřadu, aby vydal služební předpis, kterým by upravil určitým způsobem stanovenou problematiku. Toto stanovisko bylo přijato ještě před novelou ZSS č. 35/2019 Sb., která vložila do zákona $\S 11$ odst. 6 ZSS.

18 Kdo je služebním orgánem viz $§ 10$ odst. 2 ZSS.

19 Viz § 123 a 124 ZSS, které odkazují na užití úpravy v zákoníku práce. Rovněž podle závěru č. 5 ze zasedání poradního sboru náměstka ministra vnitra pro státní službu k zákonu o státní službě ze dne 3. 6. 2016 proces rozhodování o odpovědnosti státního zaměstnance nebo služebního úřadu za škodu nebo nemajetkovou újmu podle části šesté ZSS, je jedním z druhů řízení ve věcech služby; v těchto věcech tedy rozhoduje služební orgán. 
žební zákon), vztah ke správnímu řádu (v době jeho přijetí k zákonu č. 71/1967 Sb.) neupravoval, avšak sám obsahoval vlastní pravidla o řízení ve věcech služebního poměru. Dř́vější správní řád č. $71 / 1967 \mathrm{Sb}$. by se minimálně s ohledem na svůj § 2 písm. a) na řizení ve věcech služebního poměru podle zákona č. 218/2002 Sb. nepoužil. Pro srovnání lze uvést další zákony upravující služební poměr veřejnoprávní povahy. Zákon č. 221/1999 Sb., o vojácích z povolání, ve znění novely učiněné zákonem č. 272/2009 Sb., v § 144 stanoví pro řízení ve věcech služebního poměru subsidiární použití správního řádu. Zákon č. 361/2003 Sb., o služebním poměru příslušníků bezpečnostních sborů, sice vztah úpravy o řízení ke správnímu řádu neřeší, ale judikatura vychází z toho, že se obecná úprava správního řízení podle správního řádu použije subsidiárně i na řízení ve věcech služebního poměru př́islušníků bezpečnostních sborů, nebot' použití obecné úpravy není zákonem vyloučeno. ${ }^{20}$

ZSS v hlavě II části desáté, nazvané „Řízení ve věcech služby“, obsahuje pravidla o řízení ve věcech státní služby, resp. pravidla o ř́zení ve věcech služebního poměru, ${ }^{21}$ která mají přednost před úpravou správního řízení podle zákona č. 500/2004 Sb., správní rád (Sp $\mathbf{R})$.

Při vymezení, jaká procesní pravidla se uplatní při rozhodování ve věcech státní služby, zvolil zákonodárce v ZSS takovou konstrukci, že

- v $\$ 159$ odst. 1 stanoví taxativně věci služby, na rozhodování o nichž se vztahují „ustanovení o ř́zení ve věcech služby“, tedy ustanovení hlavy II části desáté ZSS, s tím, že podle $\S 160$ ZSS, nestanoví-li zákon jinak, postupuje se v řízení ve věcech služby podle $\mathrm{Spr}$, a

- v $§ 159$ odst. 2 stanoví, rovněž taxativně, na př́pady jakých rozhodování se naopak ustanovení o řízení ve věcech služby ani ustanovení správního rádu o správním rrízení nevztahují.

Uvedenou konstrukcí opomenul zákonodárce, že mohou existovat i jiné věci státní služby, o nichž rozhoduje služební orgán, se kterými však taxativní výčty v $§ 159$ odst. 1 a v $\S 159$ odst. 2 ZSS nepočítají. S ohledem na úpravu v ZSS a rozsah působnosti SpŘ vyplývající z $\S 1$ odst. 1 a 2 a $§ 177$ odst. 1 SpŘ lze rozdělit věci státní služby podle procesní úpravy rozhodování na:

1) věci služby uvedené v $§ 159$ odst. 1 ZSS, o nichž se rozhoduje podle ustanovení ZSS o řízení ve věcech služby a subsidiárně podle $\mathrm{Sp}$ Ř;

2) věci služby uvedené $\mathbf{v} \$ 159$ odst. 2 ZSS, na rozhodování o nichž se nevztahují ani ustanovení ZSS o řízení ve věcech služby, ani ustanovení SpŘ o správním řízení;

Pro rozhodování ve věcech této druhé skupiny není vyloučen $S p \check{R}$ jako celek, ale ustanovení SpǨ o správním řízení, proto není vyloučeno pro postupy služebních orgánů použití základních zásad činnosti správních orgánů ( $(2$ až $8 \mathrm{SpR})$.

3) věci služby neuvedené v $\$ 159$ odst. 1 ani 2 ZSS.

Vzhledem k tomu, že zvláštní pravidla o řízení ve věcech služby, obsažená v hlavě II části desáté ZSS, se podle $\S 159$ odst. 1 ZSS vztahují jen na věci tam uvedené, mají ty další postupy služebního orgánu ve věcech služby, jejichž účelem je vydat rozhodnutí, kterým v určité věci založí, změní nebo zruší práva anebo povinnosti jmenovitě určených

20 Srov. rozsudek NSS ze dne 22. 1. 2014, čj. 3 Ads 117/2012-26.

21 Srov. § 1 odst. 1 písm. e) ZSS: „Tento zákon upravuje... e) řízení ve věcech služebního poměru.“ 
osob, není-li pro ně výslovně vyloučena úprava správního řádu o správním řízení (věci podle $\S 159$ odst. 2 ZSS), charakter správního řízení, na které se vztahuje přímo úprava správního řízení podle SpŘ. Z úpravy ZSS obsažené v hlavě o řízení ve věcech služby by se na takové prŕípady vztahovala ustanovení kompetenční. Do této skupiny lze řadit např. již zmíněné rozhodování ve věcech náhrady škody a nemajetkové újmy podle úpravy odpovědnosti státního zaměstnance a odpovědnosti služebního úradu.

Rozhodnutí služebního orgánu vedoucí k obsazení konkrétního služebního místa jsou podmíněna dohodou s bezprostředním nadřízeným představeným k obsazovanému místu. ${ }^{22}$ Vzhledem $\mathrm{k}$ tomu, že bezprostředně nadřízeným představeným může být v tomto smyslu i např. ministr, může tím být výběr obsazování neobsazeného služebního místa výrazně ovlivněn. Bez požadované dohody by rozhodnutí služebního orgánu bylo nezákonné.

\section{VEŘEJNOPRÁVNÍ SMLOUVY PODLE ZSS}

Jedním z druhů správních činností jsou veřejnoprávní smlouvy. Základ jejich právní úpravy je obsažen v části páté Sp̌̌n, přičemž nevylučuje-li to povaha a účel veřejnoprávních smluv, použijí se na ně přiměřeně až na stanovené výjimky ustanovení občanského zákoníku ( 170 SpŘ). Zákonnou definici veřejnoprávní smlouvy obsahuje $\S 159$ odst. $1 \mathrm{SpR}$, dle něhož ,[v]eřejnoprávní smlouva je dvoustranný nebo vícestranný úkon, který zakládá, mění nebo ruši práva a povinnosti v oblasti veřejného práva“. Definice vychází z toho, že jde o „úkon“ dvou- či vícestranný, a contrario nikoli jednostranný, a z obsahu úkonu, jímž je založení, změna nebo zrušení práv a povinností v oblasti veřejného práva; definice tedy není založena na tom, kdo tvoří smluvní strany. ${ }^{23}$ Rozhodující pro to, zda určitý dvou- či vícestranný úkon, zákonem předvídaný, je veřejnoprávní smlouvou, bude jeho obsah, nikoli výslovné označení, že jde o veřejnoprávní smlouvu.

ZSS výslovně žádnou veřejnoprávní smlouvu neupravuje, tedy neupravuje nějaký úkon, který by byl takto formálně označen. Přesto je v tomto zákoně předvídáno více dohod, v souvislosti s tím pak vzniká otázka, zda se jedná či nejedná o veřejnoprávní smlouvu.

Veřejnoprávní smlouvou nejsou dohody mezi vykonavateli veřejné správy, které jsou předpokladem (náležitostí) vydání správního aktu nebo abstraktního aktu, ${ }^{24}$ když práva a povinnosti v oblasti veřejného práva vzniknou (změní se, zruší se) až jednostranným aktem, vydaným k tomu oprávněným orgánem. Veřejnoprávní smlouvou tak není dohoda podle $\S 28$ odst. 2 ZSS mezi služebním orgánem a bezprostředně nadřízeným představeným o výběru žadatele o obsazení volného služebního místa, když k obsazení

22 Viz např. $\S 28$ odst. 2 a 3, § 49 odst. 2 a $§ 51$ odst. 5 ZSS. Jen ustanovení $\S 28$ odst. 2 a 3 uvádějí, že dohoda mezi služebním orgánem a bezprostředním nadřízeným je písemná.

23 KOPECKÝ, c. d., s. 186 a 187.

24 Srov. KOPECKÝ, c. d., s. 187. Rovněž srov. LUKEŠ, Z. a kol. Československé správní právo. Obecná část. Praha: Panorama, 1981, s. 174. 
služebního místa dojde až rozhodnutím služebního orgánu o zařazení na služební místo nebo rozhodnutím o jmenování na služební místo představeného ( 330 odst. 2 ZSS). ${ }^{25}$

ZSS upravuje více dohod, které uzavírá (může uzavřít) služební orgán a státní

\section{zaměstnanec:}

- dohoda o výkonu státní služby v zahraničí (§ 67 odst. 2),

- dohoda o vyslání státního zaměstnance do mezinárodní organizace (§ 67a odst. 2),

- dohoda o zákazu konkurence ( $\$ 83$ odst. 4),

- dohoda o výkonu státní služby z jiného místa ( $\$ 117$ odst. 1$)$,

- dohoda o odpovědnosti k ochraně hodnot svěřených státnímu zaměstnanci k vyúčtování (§ 123 odst. 2 ZSS, vzhledem k $\S 123$ odst. 1 ZSS i $§ 252$ ZP).

Vzhledem k tomu, že se podle $\S 123$ odst. 1 ZSS odpovědnost státního zaměstnance za škodu, kterou zpo̊sobil služebnímu orgánu, řídí zákoníkem práce, může být uzavřena i dohoda o způsobu náhrady škody podle 263 odst. 2 ZP.

Obsahem uvedených dohod jsou práva a povinnosti státního zaměstnance $\mathrm{v}$ rámci státně zaměstnaneckého vztahu jako právního vztahu veřejnoprávního. Naplňují tak znaky veřejnoprávní smlouvy ve smyslu $§ 159$ odst. 1 SpŘ, a to smlouvy subordinační podle $\S 161$ odst. $1 \mathrm{SpǨ} .{ }^{26}$

Za veřejnoprávní smlouvu se nepovažuje kolektivní dohoda, možnost jejíhož uzavření předvídá § 143 ZSS, a to ke zlepšení podmínek výkonu státní služby, přičemž za státní zaměstnance smí kolektivní dohodu uzavřít jen odborová organizace. ${ }^{27}$

\section{SLUŽEBNÍ PŘEDPISY}

Služební předpisy vydávané podle ZSS lze řadit do širší skupiny činností veřejné správy, označované jako vnitřní předpisy, ${ }^{28}$ případně interní instrukce. ${ }^{29}$ V oboru správního práva je pojem vnitřní předpisy pojmem teoretickým, nikoli zákonným, jak je tomu v právu pracovním (viz zejm. § 305 a 306 ZP). V dřívější terminologii se pro takové úkony užívalo označení nařízení správní. ${ }^{30} \mathrm{~J}$. Hoetzel označoval služební nařízení (služební poukaz, služební instrukce) jako druh správních nařízení, dotýkajících se interna státního organismu, též jako zobecněný služební př́íkaz. Služební instrukce zakládala pro úředníka práva a povinnosti služební. Podle Hoetzela ,přiro-

25 Nemohu proto souhlasit s názorem uvedeným v komentári KOTTNAUER - PŘIB - ÚLEHLOVÁ TOMANDLOVÁ, c. d., s. 101, že dohoda podle $§ 28$ odst. 2 ZSS je veřejnoprávní smlouvou.

26 Srov. VEDRAL, J. Zákon o státní službě, správní řád a soudní řád správní. Dostupné v systému ASPI, LIT 211618CZ, stav 14. 9. 2016. Názor, že povaha dohody o odpovědnosti k ochraně hodnot svěřených zaměstnanci k vyúčtování (o hmotné odpovědnosti), je veřejnoprávní, zaujal i poradní sbor náměstka ministra vnitra pro státní službu k zákonu o státní službě (viz závěr č. 15 ze dne 8. 9. 2017), dostupné na www.mvcr.cz.

27 K soukromoprávní povaze kolektivní smlouvy viz ŠTEFKO, M. Je kolektivní smlouva soukromoprávním jednáním? Jurisprudence, 2017, č. 5, s. 32, 34.

28 Viz např. HENDRYCH, D. a kol. Správní právo. Obecná cáást. 9. vyd. Praha: C. H. Beck, 2016, s. 130; PRŮCHA, P. Správní právo. Obecná část. 8. vyd. Brno - Plzeň: Nakladatelství Doplněk a Vydavatelství a nakladatelství Aleš Čeněk, s. 275; KOPECKÝ, c. d., s. 138-140, 150.

29 Viz např. nález Ústavního soudu ze dne 5. 4. 1994, sp. zn. Pl. ÚS 49/93.

30 Viz např. HOETZEL, J. Československé správní právo. Část všeobecná. Praha: Melantrich, 1934, s. 33, 34. 
zeně jde o práva a povinnosti právní...". Soudobá německá literatura správního práva označuje takové předpisy jako správní předpisy (Verwaltungsvorschriften), které nemají bezprostřední vnější účinky, zprostředkovaně působí navenek správní praxí. Druhem těchto správních předpisů jsou služební předpisy. ${ }^{31}$

Vydávání služebních předpisů, ze kterých mohou vyplývat povinnosti pro jejich adresáty, se musí opírat o zákonný základ. ZSS v tomto směru jednak obecně uvádí, a to v § 11 odst. 1, že „služební předpis stanoví organizační věci služby“, 32 jednak předvídá vydávání blíže konkretizovaných služebních předpisů na svých jiných místech:

- $\$ 5$ odst. 3: o stanovení oborů služby pro služební místo,

- § 14 odst. 5: o přenesení rozhodování vedoucího služebního úřadu na představené,

- $\$ 15$ odst. 7: o přenesení rozhodování státního tajemníka na představené,

- $\$ 25$ odst. 5: o stanovení požadavku úrovně znalosti cizího jazyka, odborného vzdělání nebo jiného odborného požadavku potřebného pro výkon služby a způsobilosti mít prístup k utajovaným informacím,

- §35 odst. 4: o stanovení paušální částky nákladů na vykonání úřednické zkoušky,

- § 77 odst. 1 písm. m): o zřizování dalších orgánů,

- $\$ 77$ odst. 1 písm. t): o pravidlech etiky státního zaměstnance,

- \$84 odst. 3: o stanovení rozsahu, v jakém je představený oprávněn dávat státním zaměstnancům služební úkoly,

- §99 odst. 4: o podrobnějších pravidlech pro rozvržení služební doby včetně začátku a konce služební doby a pružného rozvržení služební doby,

- § 112: o úpravách v poskytování náhrad výdajů v souvislosti s výkonem služby, které se řídí př́islušnými ustanoveními zákoníku práce a kde je jinak svěřena v části sedmé zákoníku práce svěřena pravomoc zaměstnavatele,

- § 117 odst. 3: o stanovení rozvržení služební doby do směn pro účely poskytování platu při dočasné pracovní neschopnosti k výkonu služby pro státní zaměstnance, kteří vykonávají službu z jiného místa,

- §123 odst. 2: o stanovení okruhu činností, pro jejichž výkon je nezbytné uzavření dohody o hmotné odpovědnosti,

- §148 odst. 2: o stanovení výše zvláštního příplatku pro služební místa ve služebním úřadu,

- § 154 odst. 1 písm. g): o stanovení jiných údajů, které obsahuje služební průkaz,

- §155 odst. 5: o stanovení období, za které se provádí pravidelné služební hodnocení, a stanovení termínu provedení pravidelného služebního hodnocení.

Na vydávání služebních předpisů podle ZSS nelze použít úpravu vydávání vnitřních předpisů zaměstnavatele dle ZP. Ovšem odkazuje-li ZSS v některých otázkách na použití $Z P$ a tato úprava počítá s možností vnitřních předpisů dle $Z P$, rozumí se při aplikaci úpravy ZP pro tyto účely vnitřním předpisem služební předpis (viz § 124 odst. 1 ZSS).

31 Viz např. DETTERBECK, S. Allgemeines Verwaltungsrecht mit Verwaltungsprozessrecht. 14. Aufl. München: C. H. Beck 2016, s. 322.

32 Mezi organizační věci služby lze řadit např. věci systemizace služebních míst, organizační struktury služebních úřadů, hodnocení státních zaměstnanců, jejich vzdělávání či další věci, které jsou v působnosti Ministerstva vnitra dle $\S 13$ odst. 1 ZSS. 
Služební předpis nesmí být v rozporu s právním předpisem nebo služebním předpisem vydaným služebním orgánem v nadřízeném služebním úřadu nebo náměstkem pro státní službu (§ 12 odst. 1 ZSS). Zákon tak vymezuje vztah služebních předpisů $\mathrm{k}$ předpisům právním a rovněž relativní vztah mezi služebními předpisy vydanými různými služebními orgány. Zákon neřeší otázku, jaké jsou důsledky na závaznost služebního předpisu v prŕpadě, že je $\mathrm{v}$ rozporu s právním předpisem či služebním předpisem vydaným služebním orgánem v nadřízeném služebním úřadu či služebním předpisem vydaným náměstkem pro státní službu. Pro srovnání: právní předpis nižší právní síly, který by byl v rozporu se zákonem, by byl pro služební úřady a osoby vykonávající státní správu závazný do doby, než by byl zrušen (srov. např. § 2 odst. $1 \mathrm{SpŘ)}$ ).

Ohledně vnitřních předpisů dle $Z \mathrm{P}$, tedy v právu soukromém, platí, že jsou v případě rozporu s právními předpisy zcela nebo $\mathrm{v}$ dotčené části neplatné (§ 305 odst. $2 \mathrm{ZP}$ ). Služební zákon č. 218/2002 Sb. stanovil v § 10 odst. 5, že služební předpis, který je v rozporu s právními předpisy, se považuje za neplatný. Toto pravidlo v platném zákoně o státní službě obsaženo není. Protože podle zákona je služební předpis pro státní zaměstnance (a další zaměstnance, jak má na mysli § 11 odst. 3 ZSS) závazný, bude to platit i pro př́pad služebního předpisu odporujícího právnímu předpisu. Výjimka by se týkala služebního předpisu, jehož splněním by se státní zaměstnanec dopustil trestného činu nebo správního deliktu (srov. § 85 odst. 3 ve spojení s $§ 85$ odst. 4 a 5 ZSS). Protože státní zaměstnanec nesmí splnit služební př́íkaz ani služební př̌edpis, spáchal-li by jeho splněním trestný čin nebo správní delikt, není takovýto př́kaz či služební předpis pro státního zaměstnance ani závazný.

\section{ZÁVĚR}

Článek se pokusil ukázat na podstatné rysy správních činností, které se uplatňují v oboru státní služby vykonávané státními zaměstnanci. Určení povahy těchto činností je důležité jak při hledání formy a obsahu takových úkonů, tak i z hlediska možnosti obrany práv dotčených státních zaměstnanců i možnosti ochrany veřejného zájmu na zákonném postupu. Zvláštnosti vztahů v oblasti organizačních věcí státní služby oproti jiným oblastem veřejné správy spočívají $\mathrm{v}$ tom, že státní zaměstnanci vystupují jednak jako adresáti působení veřejné moci, o jejichž státněslužebních poměrech je rozhodováno, jednak vystupují jako zaměstnanci vykonávající jeden z druhů závislé činnosti, byt' ke specifickému veřejnoprávnímu subjektu - ke státu. Ačkoli právní úprava státní služby je úpravou veřejnoprávní, tím, že je na základě delegace uživána řada institutů ze základních pracovněprávních vztahů, je třeba hledat zvláštní způsoby rozhodování o těchto institutech oproti postupům známým z oblasti pracovního práva.

doc. JUDr. Martin Kopecký, CSc.

Právnická fakulta Univerzity Karlovy

kopecky@prf.cuni.cz 